\title{
Характеристика видового складу збудників при гнійних лімфаденітах у дітей та вибір антибактеріальної терапіі
}

\author{
М. О. Талько, Г. В. Філоненко
}

Національна медична академія післядипломної освіти імені П. Л. Шупика, м. Київ

\section{Characteristic of the species content of causative agents in purulent lymphadenopathies in children and choice of antibacterial therapy}

\author{
M. O. Talko, G. V. Filonenko \\ Shupyk National Medical Academy of Postgraduate Education, Kyiv
}

\begin{abstract}
Реферат
Мета. Визначити групи основних збудників при гнійних лімфаденітах (ГЛ) різної локалізації у дітей різних вікових груп; дослідити чутливість до антибіотиків домінуючих штамів для визначення антибактеріальної терапії.

Матеріали і методи. Проаналізовано результати обстеження 73 дітей за період з 2013 по 2015 р., яких лікували 3 приводу ГЛ. Досліджували матеріал та інтерпретували результати згідно з існуючими нормативними документами та методиками

Результати. Домінуючим мікробним агентом при ГЛ $€$ S. aureus $(67,6 \%)$. За результатами аналізу виявлена найбільша стійкість даного збудника до пеніцилінів - 56,3\%. Високу протимікробну активність відносно S.aureus мали аміноглікозиди, фторхінолони та оксазолідінони.

Висновки. Структура збудників ГЛ у дітей представлена грампозитивними бактеріями, серед яких основним $є$ S. aureus, однак із віком їх спектр розширюється, з'являються мікробні асоціації. Використання антибіотиків має бути обгрунтованим на основі результатів мікробіологічних досліджень та моніторингу.

Ключові слова: лімфаденіт; мікроорганізми; діти; антибіотики.

\section{Abstract}

Objective. To determine the groups of main causative agents in purulent lymphadenitis (PL) of various localization in children of different age groups; to investigate sensitivity to antibiotics of dominating strains for planning of antibacterial therapy. Materials and methods. There were analyzed the results of examination of 73 children in $2013-2015$ yrs, who were treated for PL. Material was investigated and the results interpreted in accordance to existing regulatory documents and procedures. Results. In PL S.aureus prevails among microbial agents, constituting 67.6\%. In accordance to data obtained the highest resistance of this causative agent was revealed towards penicillins $-56.3 \%$. High antimicrobial activity towards S.aureus have had aminoglycosides, fluoroquinolons and oxazolidinons.

Conclusion. The structure of causative agents of PL in children consists of gram-positive bacteria, the main of which is S. aureus, but while the age increases their spectrum widens and microbial associations evolve. Application of antibiotics must be based on results of microbiological investigations and monitoring.

Keywords: lymphadenitis; microorganisms; children; antibiotics.
\end{abstract}

Гнійні лімфаденіти (ГЛ) у дітей займають провідне місце серед інших запальних процесів м'яких тканин і дотепер залишаються актуальною проблемою. Зростання антибіотикорезистентних штамів бактерій, труднощі у диференціальній діагностиці, помилки у верифікації діагнозу, частота яких сягає 40\% [1, 2], обумовлюють пізню госпіталізацію дітей, особливо перших років життя, на стадії, що вже потребує хірургічного лікування. Необгрунтована антибактеріальна терапія (АТ) на догоспітальному етапі, недотримання правил асептики та антисептики призводять до швидкої зміни видового складу, розвитку госпітальних штамів і зростання мульти- та полірезистентних форм, що значно ускладнює перебіг післяопераційного періоду. Тому сучасні погляди щодо лікування ГЛ зводяться до необхідності проведення раціональної АТ та постійного мікробіологічного моніторингу $[3,4]$.

Мета дослідження: визначити групи основних збудників при ГЛ різної локалізації у дітей до одного року життя та старших; дослідити чутливість до антибіотиків домінуючих штамів для визначення алгоритму АТ при даному захворюванні у дітей.

\section{Матеріали і методи дослідження}

Проаналізовано результати обстеження та лікування 73 дітей за період з 2013 по 2015 р., яких лікували в хірургічному відділенні Київської дитячої клінічної лікарні № 13 приводу ГЛ. Хлопчиків було 37 (51\%), дівчаток 36 (49\%). Дітей розділено на дві вікові групи: в 1-шу групу увійшли діти у віці до одного року - 32 (43,8\%), у 2гу - діти у віці від 1 до 16 років - 41 (56,2\%). Такий розподіл дітей по групах обумовлений перебігом даного захворювання, який характеризується високою частотою ускладнень у ранньому дитячому віці. У 1 групі середній вік становив (210 \pm 83$)$ дні (від 14 днів до 1 року), середня вага - $(8,5 \pm 2,3)$ кг (від 3,6 до 12,0 кг), у 2 групі відповідно $(6,2 \pm 4,7)$ року (від 1,2 до 16 років ) та $(24,3 \pm$ 13,6) кг (від 11 до 63 кг). Серед усіх пацієнтів, яким проведено оперативне втручання, специфічний лімфаденіт діагностовано у 9 (12,3\%): запалення лімфатичних вузлів (ЛВ), асоційоване із щепленням вакциною БЦЖ (БЦЖит) - у 5 (6,8\%), феліноз - у 4 (5,5\%). Інші 64 (87,7\%) дитини мали запалення ЛВ неспецифічного характеру.

Більшість госпіталізованих паціентів мали стан середньої тяжкості. Всім проведене оперативне втручання. 
Забір біологічного матеріалу (гнійних виділень) для аналізу здійснювали інтраопераційно у стерильну пробірку. Дослідження біологічного матеріалу та інтерпретацію Отриманих результатів проводили згідно з Наказом МО3 СРСР № 535 від 22.04.1985р. Ідентифікували виділені мікроорганізми бактеріологічними методами, дотримувались класифікації Бергі (1997). У деяких спостереженнях для остаточної ідентифікації умовно-патогенних мікроорганізмів (УПМ) до виду використовували пластини для біохімічної ідентифікації ПБДЕ, ПБДС (виробництво НВО «Диагностические системы», РФ), ЕНТЕРОтест 24, СТАФІтест 16, НЕФЕРМтест 24, САNDIDАтест 24 (PLIVA-lachema, Чехія). Чутливість досліджуваних штамів визначали за допомогою дисків, на агарі МюллераХінтона диско-дифузійним методом відповідно до методичних рекомендацій «Визначення чутливості мікроорганізмів до антибактеріальних препаратів». На основі отриманих значень зон затримки росту відносили мікроорганізми до категорій чутливості (чутливий, помірно чутливий, резистентний) відповідно до критеріїв CLSI (Clinical and Laboratory Standards Institute). Статистичну обробку даних здійснювали за допомогою програм WHONET 5,6 та STATISTICA 6,0. Статистичну значущість відмінностей показників тестували за допомогою критерію Фішера. Відмінності вважали статистично значущими при $\mathrm{p}<0,05$.

\section{Результати}

Аналіз даних показав відмінності за частотою, локалізацією ГЛ та характеристикою видового складу збудників у пацієнтів 1 та 2 груп. Із 32 пацієнтів 1 групи неспецифічний лімфаденіт виявили у 28: у ділянці голови та шиї (завушний, підщелепний, шийний) - у 23 (31,5\% від усіх обстежених дітей), у ділянці верхньої кінцівки (пахвовий та ліктьовий) - у 3 (4,1\%), у ділянці нижньої кінцівки (паховий та стегновий) -у 2 (2,7\%); специфічний - у 4 пацієнтів у ділянці верхньої кінцівки (пахвовий та ліктьовий). Із 41 пацієнта 2 групи неспецифічний лімфаденіт виявили у 36: у ділянці голови та шиї (завушний, підщелепний, шийний) - у 19 (26\%), у ділянці верхньої кінцівки (пахвовий та ліктьовий) - у 10 (13,7\%), у ділянці нижньої кінцівки (паховий та стегновий) - у 7 (9,6\%); специфічний - у 5 пацієнтів: у ділянці верхньої кінцівки (пахвовий та ліктьовий) - у 4 (5,5\%), у ділянці нижньої кінцівки (паховий та стегновий) - у 1 (1,4\%).

Iз 15 дітей, які приймали антибіотики (напівсинтетичні пеніциліни - 2, захищені пеніциліни - 4, цефалоспорини - 6, макроліди - 3) на догоспітальному етапі, у 5 виявлено позитивний ріст бактеріальних культур, що вказувало на неефективність АТ, у 10 мікрофлори не виявлено.

При аналізі результатів мікробіологічних досліджень біологічного матеріалу від 73 пацієнтів всього виділено 34 культури: монокультури - у 32 хворих, мікробні асоціації - у 2. Частота виявлення бактеріальних збудників у 1 групі становила 53,1\% (у 17 хворих), у 2 - 41,5\% (у 17 хворих). У структурі збудників грампозитивні бактерії становили 100\%. До стафілококів віднесено 25 штамів, стрептококів - 2, ентерококів - у 7, у тому числі 25 - ізоляти каталазопозитивні, 9 - каталазонегативні коки. Серед коагулазопозитивних стафілококів доміну- ючим мікробним агентом, який найчастіше висівався 3 гнійних виділень (у 23 хворих) був Staphylococcus aureus (S.aureus), частка якого у загальній структурі УПМ становила $67,6 \%$. Staphylococcus epidermidis було висіяно у 2 $(5,9 \%)$ хворих. Серед каталазонегативних коків переважали Enterococcus faecium - у 5 (14,7\%), Enterococcus faecalis - у 2 (5,9\%) та Streptococcus spp. - у 2 (5,9\%) хворих.

У складі мікробних асоціацій були S.aureus i Streptococcus spp.

Порівняльний аналіз спектру збудників ГЛ виявив відмінності між досліджуваними групами пацієнтів. У пацієнтів 1 групи ГЛ найчастіше був обумовлений патогенним стафілококом - 94,1\% (n = 16), тоді як у 2 групі це було значно рідше - 41,2\% ( $\mathrm{n}=7)$. Збудники родини Streptococcus spp. (Str.pyogenes i Str.viridans) виділені в обох досліджуваних групах: відповідно 5,9\% (n=1) та $5,9 \%(n=1)$. Enterococcus spp. та S. epidermidis не виявлені у дітей першого року життя, грибкової інфекції не діагностували в жодному випадку.

За результатами аналізу 23 клінічних штамів S. aureus, виділених у пацієнтів із ГЛ, виявлено суттєві відмінності в їх чутливості до тестованих антибіотиків різних груп та класів. Найбільш резистентним даний збудник був до природних пеніцилінів: до бензилпеніциліну нечутливими були 52,2\% ( $\mathrm{n}=12)$ цих бактерій. Повна резистентність до оксациліну (метициліну) відмічена щодо 21,7\% $(\mathrm{n}=5)$ штамів S. aureus - MRSA. Нечутливість до напівсинтетичних пеніцилінів широкого спектру дії - амінопеніцилінів (амоксициліну) та цефалоспоринів III покоління (цефтриаксону) становила 21,7\% (n = 5) відповідно. Макроліди відносно штамів S. aureus мали різну активність, зокрема, резистентними до препаратів даної групи I покоління (еритроміцину) були 8,7\% (n=2) штамів, помірно чутливими - 13\% ( $\mathrm{n}=3)$. До препаратів III покоління (азитроміцину) стійкість виявлена у 4,3\% (n = 1) штамів. Резистентність до глікопептидів (ванкоміцину) становила також 4,3\% (n= 1). Аміноглікозиди (амікацин, гентаміцин, тобраміцин), фторхінолони (ципролоксацин, левофлоксацин, офлоксацин) та оксазолідінони (лінезолід) відносно штамів S. aureus мали високу активність, зокрема, резистентності до даних антибіотиків ми не спостерігали.

У ході лікування всім дітям на етапі госпіталізації було проведено оперативне втручання із розкриттям та дренуванням гнійного вогнища та подальшим призначенням АТ. Використовувалися в основному цефалоспорини II і III покоління, аміноглікозиди чи їх комбінація. Ефективним виявився лімфотропний шлях введення препаратів. Серед захищених пеніцилінів найчастіше застосовували амоксицилін/клавуланову кислоту найчастіше у дітей першого року життя за відсутності попередніх епізодів інфекційних захворювань. Середня тривалість перебування в стаціонарі пацієнтів 1 групи становила $(8,3 \pm 3,1)$ дня (від 4 до 17 днів), 2 групи - (10,3 4,7) дня (від 4 до 25 днів).

\section{Обговорення}

Аналіз отриманих результатів вказує на домінування S. aureus у структурі збудників ГЛ - 67,6\% серед виділених культур, а у дітей до одного року життя цей показник сягає 94,1\%, причому 21,7\% штамів є нечутливими 
до метициліну - MRSA, що корелює з даними в зарубіжних публікаціях [5 - 7]. Однак із віком спектр інфекційних агентів розширюється, з'являються мікробні асоціації. Виявлено зміну видового складу збудників у пацієнтів 2 групи при ГЛ шийно-лицевої ділянки із домінуванням каталазонегативних коків: Enterococcus faecium 29,4\% та Enterococcus faecalis - 11,8\% від загальної кількості висіяних культур у даній групі, частота S. aureus становила 41,2\%, що більш як удвічі менше порівняно 31 групою (94,1\%). Не висіяно в обох групах грамнегативної мікрофлори. Виражену антибактеріальну стійкість у більшості випадків зафіксовано лише до бензилпеніциліну. Виявлено зростання резистентності штамів S. aureus до напівсинтетичних та захищених пеніцилінів широкого спектру дії (амінопеніцилінів та цефалоспоринів III покоління) - 21,7\%. Макроліди відносно даного збудника мали різну активність, хоча зберігалася значна його чутливість, особливо до препаратів III покоління 95,7\%. За результатами досліджень нами встановлено, що найбільшу антибактеріальну активність щодо клінічних штамів S. aureus, виділених у дітей при ГЛ, мають гентаміцин, амікацин, тобраміцин, лінезолід, офлоксацин, левофлоксацин, ванкоміцин, азитроміцин, а найменшу група пеніцилінів. За даними зарубіжних джерел препаратами першої лінії при лімфаденіті є захищені сульбактамом чи клавулановою кислою $\beta$-лактамні антибіотики, хоча їх застосування, на нашу думку, краще лише в дітей раннього віку без ускладненого інфекційного анамнезу. В ряді досліджень відмічено високу чутливість S. aureus до кліндаміцину, що дає підставу рекомендувати його у лікуванні ГЛ. Препаратами другої лінії щодо штамів даного збудника є аміноглікозиди (амікацин, гентаміцин, тобраміцин), фторхінолони (ципрофлоксацин, левофлоксацин, офлоксацин), оксазолідінони (лінезолід) та глікопептиди (ванкоміцин), однак іх використання має бути обгрунтованим лише за результатами мікробіологічного дослідження. В рамках мікробіологічного моніторингу лікування ГЛ у дітей, на найбільший інтерес безумовно заслуговують пацієнти, що мають хронічні вогнища інфекції, пацієнти, які отримували антибіотики, а також ті, що перебували раніше на стаціонарному лікуванні, тобто вони вже мають попередню мікробну сенсибілізацію. У зв'язку з цим вивчення структури збудників, аналіз резистентності мікроорганізмів до антимікробних препаратів $є$ важливим етапом формування тактики АТ та прогнозування розвитку мікробіологічної картини даної групи захворювань. Для адекватної схеми лікування, крім природної резистентності мікроорганізмів, необхідно враховувати також, що рівень набутої резистентності шпитальних штамів дедалі зростає.

\section{Висновки}

1. Етіологічна структура збудників ГЛ у дітей всіх вікових груп представлена в основному грампозитивними бактеріями, серед яких основним лишається S. aureus (67,6\%), однак із віком спектр інфекційних агентів розширюється, з'являються мікробні асоціації.

2. Виявлено зміну видового складу збудників у пацієнтів 2 групи при ГЛ шийно-лицевої ділянки із домінуванням каталазонегативних коків: Enterococcus faecium 29,4\% та Enterococcus faecalis - 11,8\% від загальної кількості висіяних культур у даній групі.

3. Найменшу протимікробну активність щодо клінічних штамів S. aureus мали пеніциліни, найбільшу - аміноглікозиди, фторхінолони, оксазолідінони та глікопептиди. Тому застосування антибіотиків має бути обгрунтованим, слід враховувати результати мікробіологічного дослідження із визначенням антибіотикочутливості та дані мікробіологічного моніторингу.

\section{References}

1. Nahornaia NV. Bordiuhova EV, Vylchevskaia EV. Lymfadenopatyia u detei. Zdorove rebenka. 2013;6:166-76. [In Russian].

2. Tereshhenko SJu. Shejnaja limfadenopatija infekcionnoj jetiologii u detej: voprosy differencialnoj diagnostiki. Detskie infekcii. 2013;12(1):36-42. [In Russian].

3. Cucieva VV. Optimizacija lechebno-diagnosticheskoj taktiki ostryh nespecificheskih limfadenitov v detskom vozraste. [thesis]. Stavropol, $2011.23 \mathrm{~s}$.

4. Filonenko HV, Salamanina AO, Kyryk DL. Monitorynh mikrobiolohichnoho peizazhu u ditei z vrodzhenymy vadamy sertsia. Visnyk sertsevo-sudynnoi khirurhii. 2016;24(1):86-8. [in Ukrainian].

5. Novis SJ, Pritchett CV, Thorne MC, Sun GH. Pediatric deep space neck infections in U.S. children, 2000-2009. Int J Pediatr Otorhinolaryngol. 2014 May;78(5):832-6. doi: 10.1016/j.ijporl.2014.02.024. Epub 2014 Feb 26.

6. Safont M, Angelakis E, Richet H, Lepidi H, Fournier P, Drancourt M, Raoult D. Bacterial Lymphadenitis at a Major Referral Hospital in France from 2008 to $2012 \mathrm{~J}$. Clin. Microbiol. 2014 April;52(4),1161-7. doi: 10.1128/JCM.03491-13. Epub 2014 Jan 29.

7. Garca MF, Budak A, Demir N, Cankaya H, Kiroglu AF. Characteristics of deep neck infection in children according to weight percentile. Clin Exp Otorhinolaryngol. 2014 Jun;7(2):133-7. doi: 10.3342/ ceo.2014.7.2.133. Epub 2014 May 21. 